\title{
A PAKSI ATOMERÖMÚ HULLADÉKAINAK CEMENTBE ÁGYAZÁSA, ÉS A TECHNOLÓGIÁHOZ TARTOZÓ VIZSGÁLÓ LABORATÓRIUM KIALAKÍTÁSA
}
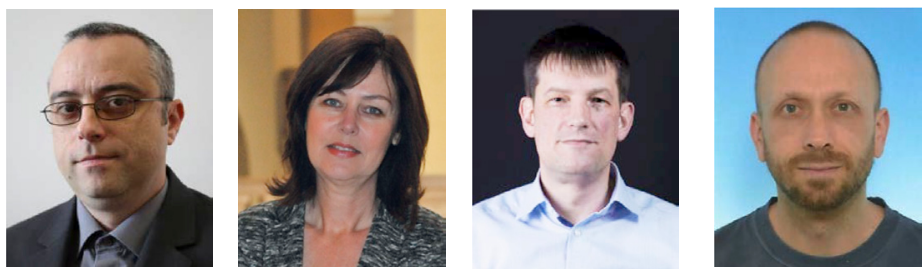

Baranyi Attila - Kopecskó Katalin - Feil Ferenc - Lukáš Gric

A Paksi Atomerömüben keletkezö kis és közepes aktivitású hulladékok kezelésére a jelenleg létesítés alatt álló cementezö technológiával új kompakt hulladékcsomagot hoznak létre, amely során a szilárd radioaktív hulladékot tartalmazó acélhordókat acélkonténerben helyezik el. A szilárd hulladékban és a hordók között lévö üregtérfogatot folyékony radioaktív hulladékok felhasználásával készült cementpéppel töltik ki. A kompakt hulladékcsomagoknak meg kell felelniük a Nemzeti Radioaktívhulladék-tároló Biztonsági jelentésében leírt hulladékátvételi követelményeinek.

A még szintén létesités alatt álló cementezett hulladékvizsgáló laboratórium feladata az elkészült cementpép tulajdonságainak gyártásközi ellenörzése, valamint az ebböl készült próbatestek nyomószilárdságának és kioldódási mértékének (diffúziós együttható) meghatározása. A laboratórium felszerelése és a cement/beton iparban használatos eszközök tesztelése során kiderült, hogy sok esetben speciális öntőformákra van szükség, a radioaktív cementpép kis viszkozitása és korrozív tulajdonságai miatt. Ezen kívül fontos követelmény, a radioaktív cementkö nyomószilárdságának mérése során keletkezö törmelék összegyüjtése, és a kiporzás minimalizálása.

Kulcsszavak: cementezés, radioaktív hulladékkezelés, cementpép vizsgálat, cementkő vizsgálat

\section{BEVEZETÉS}

A Paksi Atomerőműben létesítés alatt áll a radioaktív hulladékcementező technológia, melynek segítségével a tovább már nem tisztítható folyékony radioaktív hulladékok felhasználásával cementpépet állítanak elő. Az erőmüben keletkező kis és közepes aktivitású szilárd radioaktív hulladékokat tartalmazó acélhordókat vékonyfalú acélkonténerbe helyezik, majd a radioaktív cementpépet a konténerbe töltik, ezzel egy új hulladékformát, ún. kompakt hulladékcsomagot (továbbiakban KHCS) hoznak létre.

A kompakt hulladékcsomagnak, így a cementbe ágyazott radioaktív hulladéknak is meg kell felelnie a Nemzeti Radioaktívhulladék-tárolót (NRHT) üzemeltető Radioaktív Hulladékokat Kezelő Kft. által kiadott Üzemeltetést megalapozó biztonsági jelentésében leírt hulladékátvételi követelményeknek (továbbiakban HÁK, Radioaktív Hulladékokat Kezelő Kft., 2018), amelyet egy vizsgáló laboratórium fog ellenőrizni. Amennyiben a kompakt hulladékcsomag minden szempontból megfelel a HÁK-nak, akkor a Bátaapátiban müködő NRHT-ban kerül végleges elhelyezésre.

A jelen állapotban még létesítés alatt álló cementezett hulladékvizsgáló laboratórium felszerelése során természetesen a cement/beton vizsgálat során alkalmazott szabványos módszereket és eszközöket kívántuk használni, de a radioaktív cementpép speciális tulajdonságai miatt sok esetben változtatni kellett a vizsgálati eljárásokon, és eszközökön. A laboratórium egyrészt a radioaktív cementpép egyes tulajdonságainak gyártásközi ellenőrzését, másrészt a megszilárdult cementkő HÁK-nak való megfelelőségét fogja vizsgálni annak érdekében, hogy a kompakt hulladékcsomag hosszútávú elhelyezése biztonságosan megvalósítható legyen.

A jelen tanulmány a cementbe ágyazott hulladékcsomag kialakítását, az átvételi követelményeket és a vizsgáló laboratórium kialakítását taglalja.

\section{A PAKSI ATOMERÖMÜBEN KELETKEZÖ RADIOAKTÍV HUL- LADÉKOK}

A radioaktív hulladékok fogalmának meghatározásával és felosztásával a 487/2015 (XII.30) Korm. rendelet foglalkozik. Radioaktív hulladéknak tekinthető minden olyan anyag, amely valamilyen tervezett nukleáris tevékenység során keletkezik, és további felhasználására már nincs igény, ugyanakkor a benne lévő radioizotópok koncentrációja meghaladja a környezetbe történő, és biztonságosnak tekintett kibocsátás, vagy kihelyezés (deponálás) határértékeit (MVM Paksi Atomerőmü Zrt., Éves jelentés, 2019).

A kormányrendelet, így az atomerőmü is nagyon kis, kis, közepes és nagy aktivitású, valamint szilárd és folyékony radioaktív hulladékokat különböztet meg.

Az atomerőmüben keletkező szilárd hulladékok forrásai:

- elhasználódott és felaktiválódott, vagy felületileg 
szennyezett szerelvények, berendezések, csővezetékek, hőszigetelések stb.,

- átalakításokból származó építési anyagok (betontörmelék, faanyag, üveg stb.), illetve különböző elszennyeződött fémhulladékok, kábelek stb.,

- karbantartó mühelyekben képződött fémhulladékok, elhasználódott szerszámok, forgácsok,

- karbantartás és üzemeltetés során keletkezett ún. «puha» hulladékok (ruhák, egyéni védőfelszerelések, szürőbetétek, törlörongyok, fóliák stb.).

A szelektíven gyűjtött nem tömöríthető és tömörített („puha”) hulladékok speciális (belül müanyag bevonattal ellátott) 200 literes, 1,2 mm falvastagságú fémhordókba (Ø 571,5×880 mm) kerülnek.

A hordók radiológiai minősítésük után az erőmüben kerülnek átmeneti tárolásra.

Az atomerőmüben keletkező folyékony hulladékok típusai:

- bepárlási maradékok (sürítmények),

- evaporátor savazó oldat,

- használt primerköri ioncserélö gyanták,

- dekontamináló oldatok,

- ülepítő iszapok,

- aktív oldószerkeverékek.

A felsorolt hulladékokat az erőmü ellenőrzött zónájában tárolják 400-550 $\mathrm{m}^{3}$-es saválló acél tartályokban további feldolgozásig. Jelenleg az Atomerőműben a folyékony hulladék kezelésére elsősorban a Folyékony Hulladékvíz Feldolgozó Technológiát (FHFT) alkalmazzák. Az eljárással a kezelhető bepárlási maradékokból eltávolítják a radioaktív szennyezéseket, és kinyerik az inaktív bóraxot, amelyet a továbbiakban egyszerủ veszélyes hulladéknak megfelelően kezelnek. A többi hulladékáramot, illetve az alfasugárzó izotópokat (transzuránok) nagyobb mennyiségben tartalmazó, a 2003-as üzemzavart követően keletkezett bepárlási maradékokat a cementező technológiával fogják kezelni.

\section{Bepárlási maradékok}

Az atomerőmü ellenőrzött zónájában különböző eredetủ radioaktív izotópokkal szennyezett vegyszeres hulladékvizek keletkeznek, amelyek szelektív gyüjtésére nincs lehetőség. Ezek az oldatok kis koncentrációban tartalmaznak szárazanyagot (3-5 $\mathrm{g} / \mathrm{dm}^{3}$ ), többek közt a primerkör vízüzeméhez, dekontaminálási célokra, a víztisztítók regenerálására használt oldott vegyszereket, és a reaktorteljesítmény finomszabályozására használt bórsavat. Az összegyüjtött hulladékvizeket a kisebb térfogatban való tárolás érdekében bepárolják, erre a célra mindkét kiépítésen egy-egy bepárló berendezés szolgál. (Egy kiépítésen két blokk és azok berendezései találhatók. Az egyes kiépítésen tehát az 1-2 reaktor, a kettes kiépítésen 3-4 reaktor helyezkedik el külön épületrészekben.) A bepárolt oldat $\mathrm{pH}$-ját $\mathrm{NaOH}$-val állítják be 12 -re $(\mathrm{Na}: \mathrm{B} \approx 1)$ a borátok nagyobb oldhatóságának elérése érdekében. A bórsav $\left(\mathrm{H}_{3} \mathrm{BO}_{3}\right)$ oldhatósága $20{ }^{\circ} \mathrm{C}-o n$ 5,04-g/100 $\mathrm{cm}^{3}$ (Pungor, 1987), míg a $\mathrm{NaBO}_{2}$ (nátrium-metaborát) formájában már $20,22 \mathrm{~g} / 100 \mathrm{~cm}^{3}$ oldódik (Blasdalae - Slansky, 1939). Az így létrehozott bepárlási maradékok (sűrítmények) 180-200 $\mathrm{g} / \mathrm{dm}^{3}$ koncentrációban tartalmaznak bórsavat (borátokat). Többek között ez is okozza a sürítmények nagy (350-400 g/ $\mathrm{dm}^{3}$ ) szárazanyag tartalmát, amelyet a hulladék cementbe ágyazásánál figyelembe kell venni.

\section{Evaporátor savazó oldatok}

Az előző pontban említett bepárló berendezéseket időnként salétromsavas mosásnak vetik alá a bepárlás után kialakult lerakódások eltávolítása céljából. A visszamaradt oldat pH-ja 1-alatti, és a bórsav koncentrációja is viszonylag kicsi (kb. $\left.50 \mathrm{~g} / \mathrm{dm}^{3}\right)$.

\section{Ülepítö iszapok}

A folyékony radioaktív hulladékok kezelésének egyik lépése a csurgalékvizek (a padlóösszefolyókból származó folyadékok) ülepítése. A feladatot mindkét kiépítésen egy-egy $550 \mathrm{~m}^{3}$ ülepítő tartály végzi, amelyben a szilárd szennyezők leülepednek a tartály aljára.

\section{Használt ioncserélö gyanták}

A primerköri víztisztítókból származó kation- és anioncserélö gyanták keveréke, amelyet a segédépületben található egyegy tartályban tárolnak. Az ioncserélő gyanta hulladék ún. transzportvíz alatt található, amelyet a kimerült gyanta manipulációjára használnak. Ezt a hulladékot a transzportvíz savas kémhatása $(\mathrm{pH}=23)$, kis bórsav koncentrációja (1-3 g/ $\mathrm{dm}^{3}$ ), ill. a gyanta nagy radioaktivitása (dózisteljesítménye) jellemzi.

\section{Dekontamináló oldatok}

A 2. blokk súlyos üzemzavar helyreállítási munkálatai során keletkezett dekontamináló oldatok. Ez a hulladék kisebb (kb. $15 \mathrm{~g} / \mathrm{dm}^{3}$ ) bórsav koncentrációjú, lúgos kémhatású ( $\mathrm{pH}=$ 10) és viszonylag kis mennyiségben tartalmaz szárazanyagot $\left(<20 \mathrm{~g} / \mathrm{dm}^{3}\right)$.

\section{A CEMENTEZŐ TECHNOLÓGIA BEMUTATÁSA}

A cementező technológia segítségével a tovább már nem kezelhető folyékony radioaktív hulladékokat végleges tárolásra alkalmas szilárd halmazállapotba hozzák, és egyúttal a szilárd hulladékok között lévő szabad üregtérfogatot is csökkentik az NRHT hatékonyabb kihasználtságának érdekében. A 1. ábrán a cementező technológia elvi sémája látható. A,segédépületi tartálypark" TW jelölésű (alfanumerikájú) tartályaiból a folyékony radioaktív hulladék egy homogenizáló tartályba kerül, amelyet kémiai és radiokémiai elemzésnek vetnek alá. Itt még lehetőség van az oldat pH-jának beállítására, a cementezési receptúra finomhangolására, valamint a homogén hulladékoldat előállítására.

\section{A cementezö technológia feladatai:}

- A nem tömörített, jellemzően fémhulladékokat, építési törmeléket, illetve utószüröket tartalmazó, 200 l-es fémhordókban lévő szabad üregek kitöltése folyékony radioaktív hulladékok felhasználásával készült cementpéppel.

- Négy db 200 1-es hordót tartalmazó konténer szabad térfogatának kitöltésére folyékony radioaktív hulladékból készült cementpéppel.

- Üres konténer kitöltése folyékony radioaktív hulladékból készült cementpéppel.

\section{A kompakt hulladékcsomag (KHCS) elkészitésének menete}

A kiválasztott, minősített szilárd hulladékokat tartalmazó 200 l-es acélhordókat fedéllel, vagy fedél nélkül vékony falú acélkonténerbe helyezik (2. ábra). - A tömörített (préselt) „puha” hulladékokat (ld. 2. fejezet) tartalmazó hordók fedelét nem távolítják el. - A hordók tetejére egy hegesztett acélhálót helyeznek, amelyet egy leszorító szerkezettel rögzítenek az esetleges hulladék és a hordó felúszásának megakadályozására. 


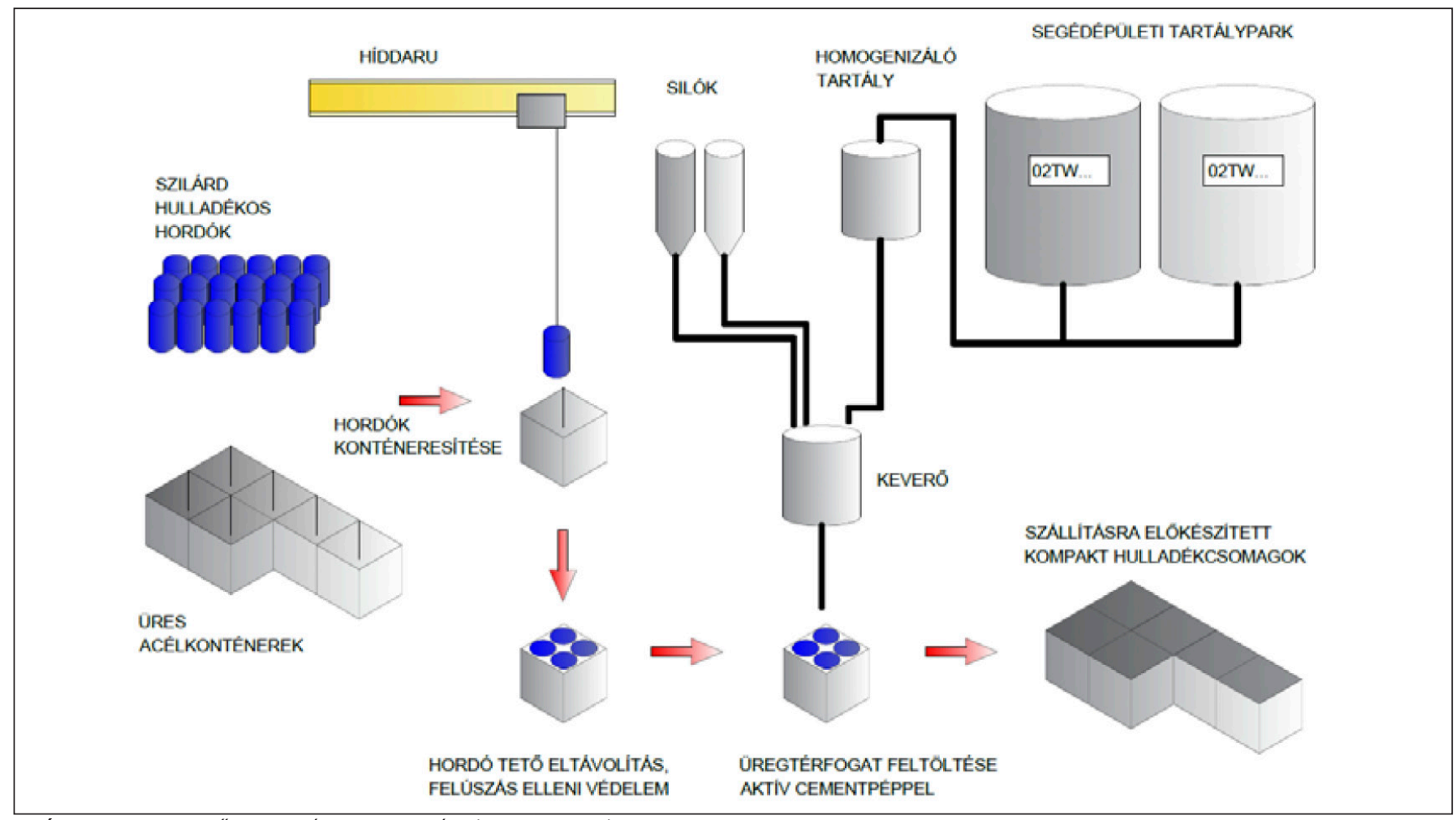

1. ábra: A cementezó technológia bemutatása (Kappel, 2021)
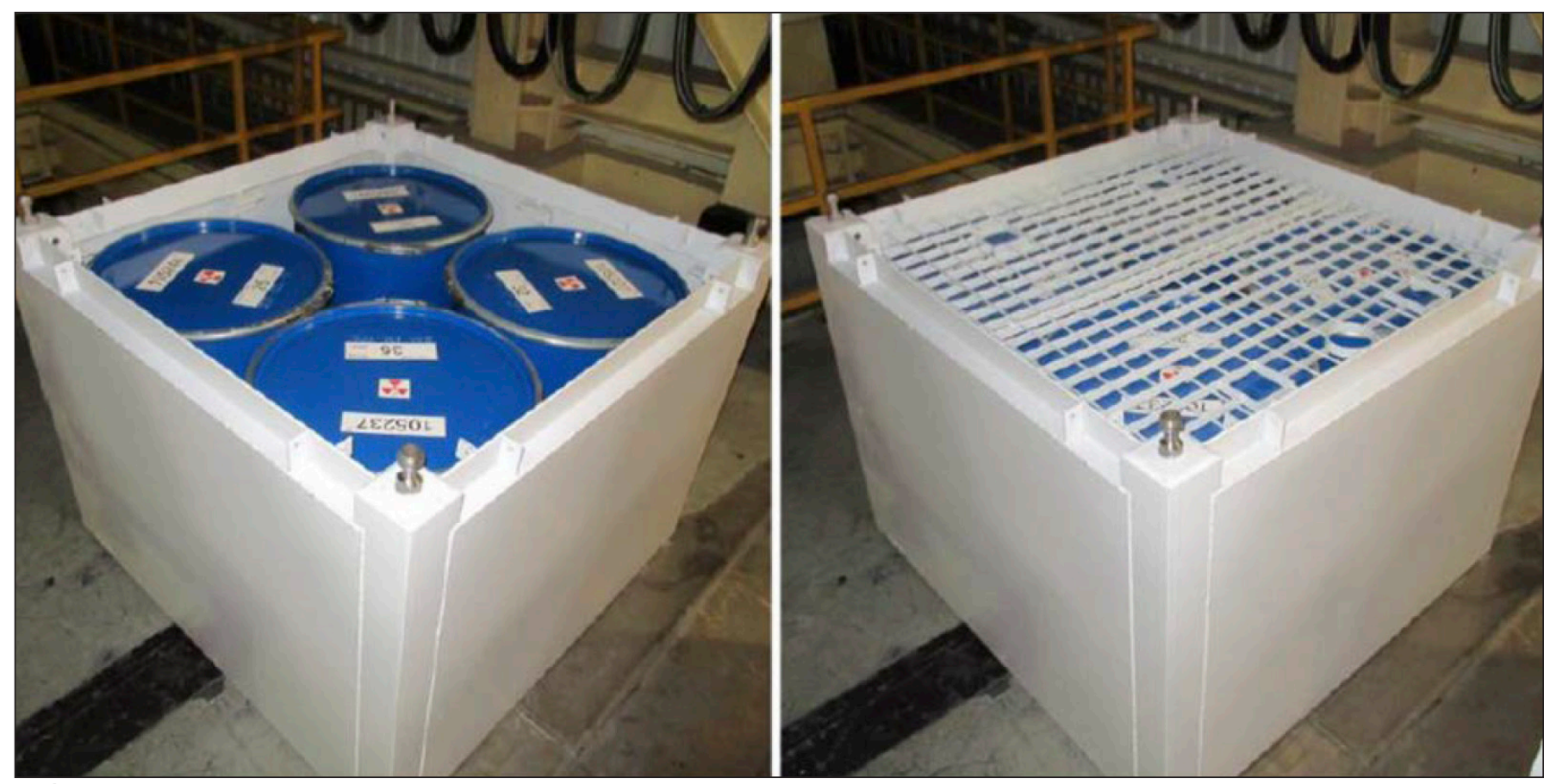

2. ábra: Az ágyazásra előkészített konténer

Az előkészített konténert daruval ráemelik a görgősorra (1. ábra), ahonnan a konténertöltő rendszer (mixer) alá kerül. A homogenizált folyékony hulladékot a kivitelező cég által megadott receptúra szerint összekeverik cement-kiegészítő anyag porkeverékkel, majd az alaposan homogenizált cementpépből mintát vesznek a vizsgáló laboratórium számára.

Egy keveréssel kb. 2301 cementpépet engednek a konténerbe, amelyet 5-6 keveréssel tudnak teljesen feltölteni. A hulladékcsomagot minden második keverést követően 10 s-on keresztül 50 Hz-en vibrálják a görgösor alatt elhelyezett vibromotorok segítségével, a hulladékban lévő szabad üregek és a cementpépben lévő légbuborékok csökkentése érdekében. Amikor a konténer megtelt, a görgősoron a tárolási helyre szállítják, ahol a cementpép megszilárdul (3. ábra).

A cementezést követő második napon (a lassú kötés miatt) megtörténik a KHCS első ellenőrzése:

- kivérzés mértékének meghatározása,

- kitöltöttség ellenőrzése,

- cementpép felületének vizuális vizsgálata,

- felületi keménység mérése (amennyiben lehetséges),

- konténer felületi hömérsékletének mérése.

A KHCS végleges ellenőrzése a konténer végleges elhelyezésre való átadása előtt 1-2 nappal történik a

- KHCS tömegének ellenőrzése,

- maximális és átlagos felületi dózisteljesítményének meghatározása,

- nem fixált felületi szennyezettség meghatározása,

- felületi keménység mérése,

- konténer felületi hömérsékletének mérése, 


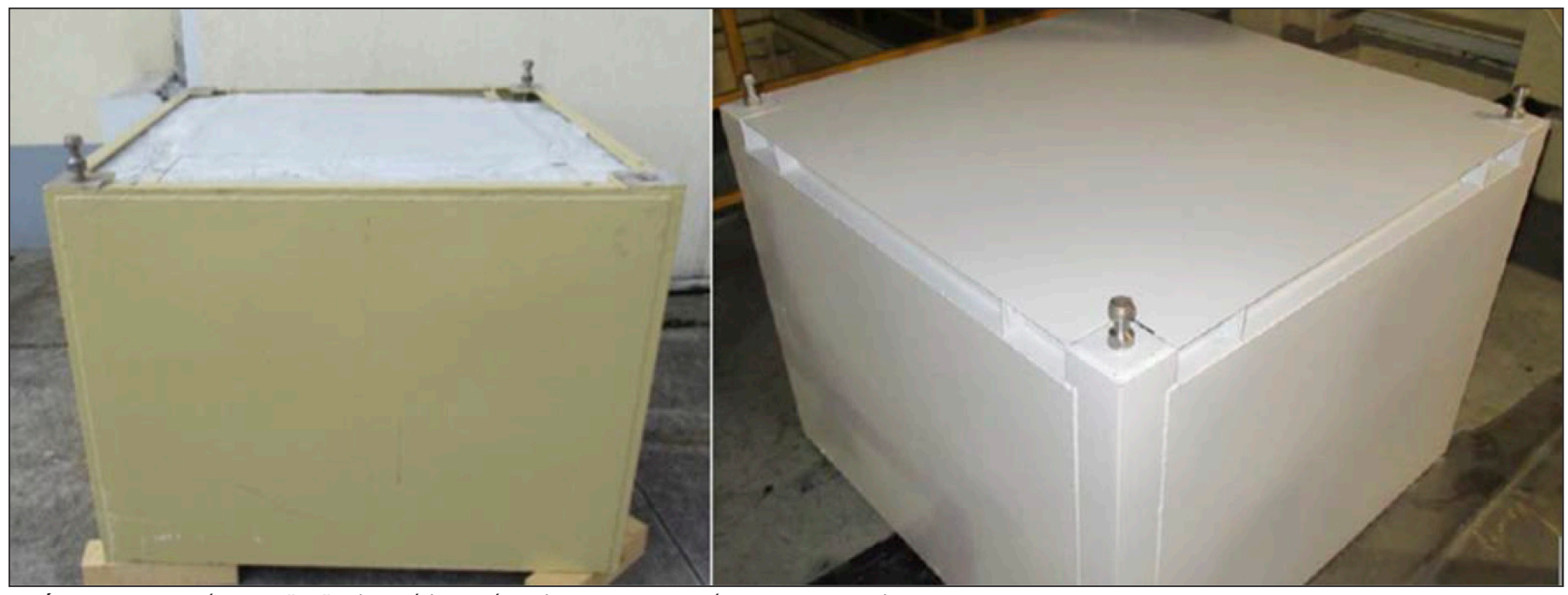

3. ábra: Cementpéppel kiöntött (inaktív) konténer (kompakt hulladékcsomag, KHCS)

- külső vizuális vizsgálata (festés épsége, deformáltság, korróziós nyomok stb.).

\section{A CEMENTEZETT RADIOAKTÍV- HULLADÉK-VIZSGÁLÓ LABORA- TÓRIUM}

\subsection{A laboratórium feladatai}

A laboratórium által végzett vizsgálatok kiterjednek a folyékony radioaktív hulladékok felhasználásával készült cementpép gyártásközi ellenőrzésére, és a megszilárdult cementkő meghatározott tulajdonságainak mérésére.

A cementpép-vizsgálatok a következők:

- konzisztencia

- testsürüség

- kötési idő

- kivérzés - zsugorodás

- hőfejlődés-vizsgálat.

A cementkő vizsgálatok az alábbiak:

- testsürüség

- nyomószilárdság

- diffúziós együttható meghatározása.

Minden vizsgálat során nagy figyelmet kell fordítani arra, hogy a cementpép, ill. cementkő radioaktív tulajdonságú (nyílt sugárforrás). A munkát természetesen az ellenőrzött zónában használatos kötelező védőruhában (overál), gumikesztyű, cipővédő lábzsák és védőszemüveg használata mellett kell végezni. A nyomószilárdság-mérést és az esetleges receptúra ellenőrzés során végzett próbakeverés közben pedig légzésvédőt is fel kell venni. A munka során törekedni kell a mintákkal való közvetlen érintkezés csökkentésére, az ALARA (As Low As Reasonably Achievable) elv szem előtt tartása mellett.

\subsection{A vizsgálati szabványok átte- kintése}

A cementbe ágyazott folyékony radioaktív hulladékok vizsgálata során törekedtünk arra, hogy minden mérés szabvány alapján történjen.

Az első gondot az okozta, hogy milyen anyagnak tekintsük a vizsgálandó cementezett termékeket, mivel az csak folyékony radioaktív hulladékot, cementet (CEM I 42,5 N) és kiegészítőanyagot (kalcinált alumíniumszilikát) tartalmaz. A folyékony radioaktív hulladékok általában nagy oldott só (főleg borát) és szárazanyag tartalmú vizes oldatok, amelyek közül a legfontosabbak a bepárlási maradékok (sürítmények), ezért a cementezési kampány ennek a hulladéktípusnak a feldolgozásával fog indulni. Az először kezelésre kerülő folyékony hulladék összetételét a $1 . a, b$ táblázat mutatja.

A radioaktív cementpép és a kötés után kialakult cementkő tulajdonságainak meghatározására a cement, beton és habarcs vizsgálati szabványok nem, vagy csak korlátozottan használhatóak.

- Az MSZ EN 196-1 meghatározott receptúrát és keverési módot ír elö a próbatest készítéséhez: keverési sebesség, ejtőasztalos tömörítés, CEN-szabványhomok, ioncserélt víz. Az általunk vizsgált cementpéphez használt „,keverővíz” azonban nagy sótartalmú oldat, és a cementpép nagy v/c

1.a táblázat: A 02TW80B003 tartályban (550 m³) lévő sürítmény összetétele

\begin{tabular}{|c|c|c|c|c|c|}
\hline $\mathrm{pH}$ & Nitrát $\left[\mathrm{g} / \mathrm{dm}^{3}\right]$ & Bórsav $\left[\mathrm{g} / \mathrm{dm}^{3}\right]$ & Mólarány $\left(\mathrm{NaOH} / \mathrm{H}_{3} \mathrm{BO}_{3}\right)$ & Sürüség $\left[\mathrm{kg} / \mathrm{dm}^{3}\right]$ & Szárazanyag $\left[\mathrm{g} / \mathrm{dm}^{3}\right]$ \\
\hline 12 & 22,59 & 184,54 & 1,08 & 1,232 & 362,60 \\
\hline
\end{tabular}

1.b táblázat: A 02TW80B003 tartályban lévő sűrítmény összetétele [mg/dm3] (ICP-spektrometria)

\begin{tabular}{|c|c|c|c|c|c|c|}
\hline $\mathrm{K}$ & $\mathrm{Na}$ & $\mathrm{Cr}$ & $\mathrm{Mn}$ & $\mathrm{Fe}$ & $\mathrm{Co}$ & $\mathrm{Ni}$ \\
\hline $2,87 \mathrm{E}+03$ & $1,03 \mathrm{E}+05$ & $1,90 \mathrm{E}-01$ & $2,79 \mathrm{E}+00$ & $<2,00 \mathrm{E}-02$ & $5,70 \mathrm{E}-01$ & $1,24 \mathrm{E}+01$ \\
\hline $\mathrm{Cu}$ & $\mathrm{Li}$ & $\mathrm{Ca}$ & $\mathrm{Zn}$ & $\mathrm{Cd}$ & $\mathrm{Si}$ & $\mathrm{SiO} 2$ \\
\hline $9,16 \mathrm{E}+00$ & $1,29 \mathrm{E}+01$ & $2,36 \mathrm{E}+02$ & $3,83 \mathrm{E}+00$ & $8,20 \mathrm{E}-01$ & $3,92 \mathrm{E}+01$ & $8,39 \mathrm{E}+01$ \\
\hline
\end{tabular}


tényezője miatt túl kicsi a viszkozitása ahhoz, hogy a megadott fordulatszámokon készítsük el. A szabványnak csak a cementezési receptúra ellenőrzés során van jelentősége, mivel normál üzemi körülmények között a cementpép előállítása és a mintavételezés az üzemben történik.

- Az MSZ EN 196-3 szabványos folyósságú cementpép vizsgálatára vonatkozik. A radioaktív cementkő előállításánál viszont a cél, hogy minél nagyobb mennyiségü folyadék (minél nagyobb v/c) kerüljön szilárd halmazállapotba a lehető legkisebb térfogat növekedés mellett.

- Az MSZ 4798:2016 szerinti megfogalmazás szerint a beton „Cement, durva és finom adalékanyag, valamint viz összekeverésével készitett anyag adalékszerekkel, kiegészitöanyagokkal, illetve szálakkal vagy azok nélkül, és amelynek tulajdonságai hidratáció révén - a beton- öszszetételtöl, a bedolgozástól, az utókezeléstöl és a környezeti körülményektöl függöen - alakulnak ki. " Ezzel szemben a folyékony hulladék felhasználásával készült cementpépek (a kimerült ioncserélő gyantát tartalmazó hulladékokat kivéve) nem tartalmaznak adalékanyagot, így nem tekinthetők betonnak.

- Az MSZ EN 1015-11 szabvány 7.2 fejezetében leírt próbatest készítési procedúra a radioaktív cementpéppel nem kivitelezhető annak kis viszkozitása (nagy v/c) miatt, ill. jelentős másodlagos radioaktív hulladék termelődésével járna. Minden olyan anyag, amely a cementpéppel, vagy cementkövel érintkezik és a szennyezödés eltávolitása (dekontamináció) nem lehetséges, radioaktív hulladékot képez.

- Az MSZ EN 998-1 szabvány pedig szintén (vakoló) habarcsokra vonatkozik.

\subsection{Radioaktív cementpép vizsgá- latok}

A receptúra kidolgozás és ellenőrzés során a próbatestek előállítását az MSZ EN 196-1 szabványban előírt Controls 65-L0502 típusú keverőgéppel állítottuk elő, de a keverék kis viszkozitása miatt a fordulatszámot csökkentenünk kellett max. 200 rpm-re.

\subsubsection{Konzisztencia vizsgálat}

Az MSZ EN 1015-3 jelzetü falszerkezeti vizsgálati szabvány egy ejtőasztalos vizsgálat, mely szerint az ejtőasztal lapjára egy saválló acélból vagy rézből készült ,,meghatározott forma segitségével az ejtöasztal lapjára friss habarcsot teszünk". A habarcs az ejtőasztal egyenletes frekvenciával történő ejtés során szétterül, melynek tolómérővel megmérjük az átmérőjét. Az ejtőasztal lapjának átmérője mindössze 300 mm, ezért attól tartottunk, hogy a radioaktív cementpép terülése túl nagy lenne, és lefolyna arról.

A betonterülés mérésére használt szabvány (MSZ EN 12350-5) 700x700 mm méretü terülésmérő asztalt ír elö, amelynek közepére kell tenni a szabványos csonka kúp formájú öntőformát. A megnedvesített sablont két egyenlő rétegben meg kell tölteni a vizsgálandó betonkeverékkel, majd a bedolgozás után a felső réteget le kell simítani acélvonalzóval. A bedolgozás után $30 \mathrm{~s}$-al a kúpformát leemeljük, majd 15-ször leejtjük az asztalt, és megmérjük a beton átmérőjét. Esetünkben a szabvány alkalmazása több okból nem célszerü. Egyrészt az általunk vizsgált cementpép radioaktív, ezért törekedni kell az indokolatlan kontamináció (szennyeződés) elkerülésére. A cementpép nagy v/c tényezője ebben az esetben túl nagy terülést okozott volna a pép kis viszkozitása miatt, és lefolyt volna az asztalról.

Mivel a kezdeti receptúra kísérletek a Suttard módszer szerint zajlottak, ami dozimetriai szempontból sem okozott problémát (a kis mennyiségű minta miatt), megtartottuk ezt a vizsgálatot. A mérés során a cementpépet egy skálával ellátott vízszintes felületen elhelyezett $\varnothing 50 \times 100 \mathrm{~mm}$ acélhengerbe töltjük, majd határozott mozdulattal felemeljük a sablont. Lemérjük a szétterült cementpép átmérőjét két irányban. Annyit kellett változtatni az eredeti módszeren, hogy üveglap helyett a mérést egy laminált, skálával ellátott milliméterpapíron végezzük, amelynek hajlíthatósága és tisztíthatósága révén a radioaktív cementpép könnyen és felesleges szennyeződés nélkül áttölthető a megfelelő helyre.

\subsubsection{A cementpép testsürüségének vizsgálata}

A cementpép sürüségének meghatározását az MSZ EN 12350-6 szabvány alapján végezzük, azonban az eljárásban előírt minimálisan alkalmazandó 5 1-es edény helyett 1 l-es edényt használunk. Ezt a méretcsökkentést abból a megfontolásból hajtottuk végre, hogy a cementpép nem tartalmaz adalékanyagot (nem beton), ezért ebben a méretben is homogénnek és reprezentatívnak tekinthető a mérés. A méretcsökkentésnek másik oka a már említett ALARA elv szem előtt tartása, így a felesleges dózisnövekmény elkerülése. A mérést tehát egy kalibrált 1 l-es saválló edényben, vibrálást követően végezzük. A kalibráláshoz üveglap helyett, könnyü plexilapot használunk.

\subsubsection{A kötési idő meghatározása}

A cementpéppel szemben támasztott egyik fontos követelmény, hogy a kötési idő kezdetének meg kell haladnia a 2 órát és a kötésnek be kell fejeződnie 48 órán belül. A korai kötés elkerülésére azért van szükség, hogy elkerüljük a cementpép mixerben való kötését, valamint könnyen a konténerbe lehessen tölteni. A túl hosszú kötési idő akadályozza a hulladékcsomaggal való manipulációt és a szállíthatóságot.

A mérésekre az MSZ EN 196-3 szabványnak megfelelö automata Vicat-készüléket használunk. A szabványban előírt szabványos folyósságú keverék készítési előírásának és a vizsgálati körülményeknek (laboratórium hőmérséklete és páratartalma) nem tudunk megfelelni, mivel a Paksi Atomerőmü helyiségeiben állandó dekompressziót kell fenntartani. A gyártásközi ellenőrzések során a cementpépet nem a laboratórium készíti, hanem a keverőtartályból fogunk mintát venni, illetve a keveréshez sem vizet, hanem folyékony radioaktív hulladékot használunk.

A bepárlási maradékok nagy bórsav (borát) és szerves anyag tartalma miatt a cement kötési ideje megnő (Csetényi - Glasser, 1995; Davraz, 2010; Kratochvíl et al., 2014), ezért a Vicatkészülék ejtései között sem tudjuk tartani a szabványos $5 \mathrm{~mm}$ távolságot. A sürítmény felhasználásával készült cementpépek viszkozitása sokkal kisebb a szabványos folyósságú keverékénél, ezért a szabványos Vicat-gyürüből a cementpép a gyürü és az üveglap érintkezésénél kifolyt. Ezért szükség volt egy új, speciális cementpép vizsgálatára is alkalmas Vicat-öntőforma tervezésére (4. ábra), amely megfelel a szabványnak, ugyanakkor megtartja a kis viszkozitású pépet szivárgás nélkül.

A kötési idő a sürítmény borát tartalmának köszönhetően rendkívül hosszú, akár 80 óra is lehet ugyanakkor valószínüleg az oldatban lévő szerves anyag miatt a cementpép sok esetben rátapadt a Vicat-türe (5. ábra). Ez a jelenség lehetetlenné 


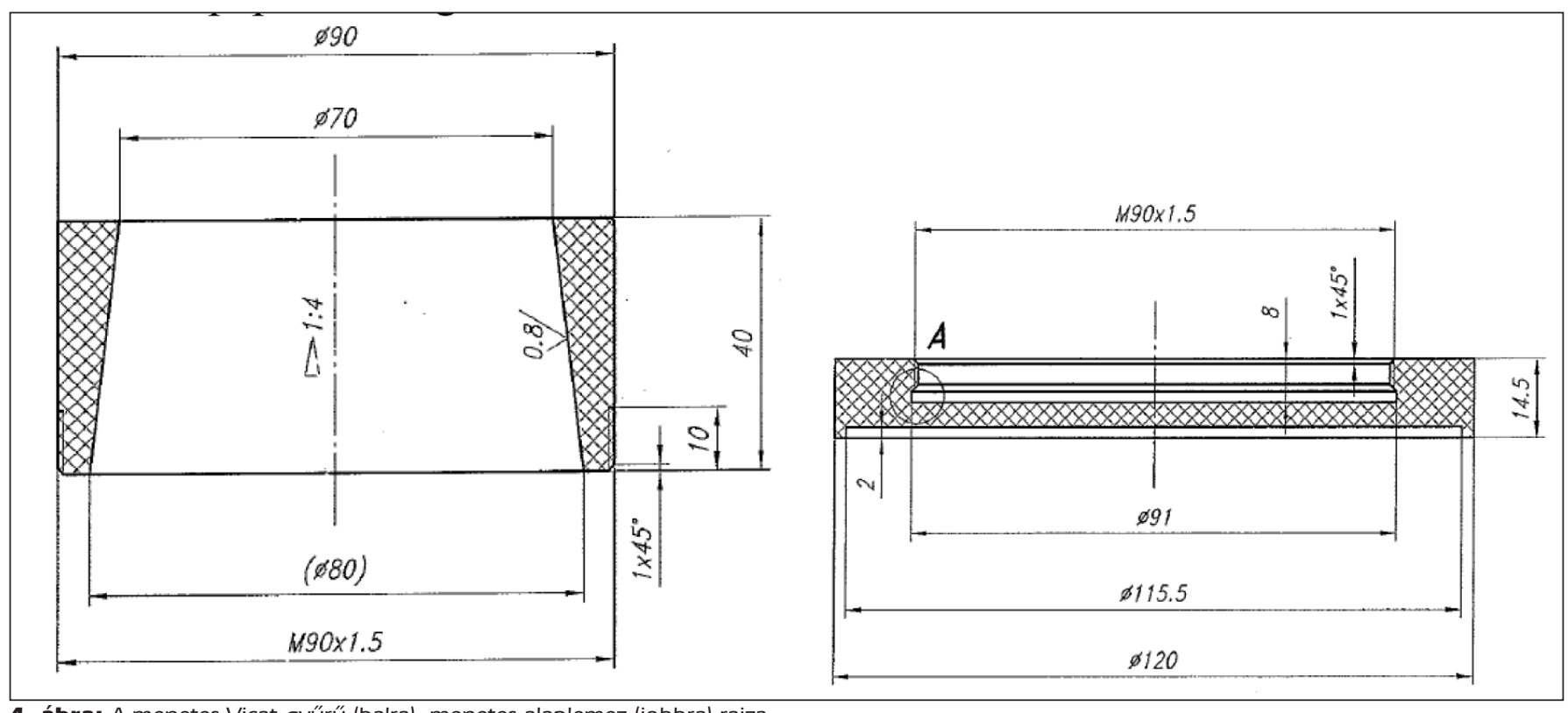

4. ábra: A menetes Vicat-gyűrü (balra), menetes alaplemez (jobbra) rajza

teheti a mérést, ezért kísérleteket végeztünk a cementpép kötési idejének féladiabatikus módszerrel (Wang et al., 2007; Rolo, 2013, Sedaghat et al., 2013) történő meghatározására is (4.3.4 fejezet).

\subsubsection{Hőfejlődés-vizsgálat}

A kompakt hulladékcsomaggal, így a cementpéppel szemben támasztott egyik követelmény, hogy a hidratáció során fellépő maximális hőmérséklet nem haladhatja meg a $80{ }^{\circ} \mathrm{C}$-ot. Ezt a feltételt a receptúra kidolgozása és ellenőrzése során laboratóriumban, ill. a kampány kezdetén a konténerben (KHCS) is ellenőrizni kell.

A laboratóriumi mérésre egy min. $10 \mathrm{~cm}$ falvastagságú, $300 \times 400 \times 300$ mm méretü polisztirol kalorimétert használunk, amelybe helyezzük a müanyag fözőpohárba töltött 11 (1800 1900 g) cementpépet. A vizsgálandó minta közepébe helyezzük a teflonnal bevont termoelemet, egy másik érzékelővel a szobahőmérsékletet rögzítjük. Az adatokat egy Comet M1200 hőmérséklet adatgyüjtővel rögzítjük, majd az eredményeket számítógéppel értékeljük.

A kötési idő hőfejlődés-vizsgálaton alapuló meghatározásával kapcsolatos kísérleteink sajnos nem jártak sikerrel, mert a cementpép nagy bórsav koncentrációja miatt a kötési folyamat speciális módon megy végbe. Ez azt jelenti, hogy a Vicat-módszer szerinti kötési idő kezdete és vége állandó hőmérsékleten $\left(30-35^{\circ} \mathrm{C}\right)$ lejátszódik, így nem alkalmazható sem a deriváltak, sem a frakciók módszere (Wang et al., 2007, Rolo, 2013) azok meghatározására.

\subsubsection{Kivérzés- és zsugorodásvizsgálat}

A jelenleg alkalmazott módszer szerint egy zárható mintavételi poharat $40 \mathrm{~mm}$ magasan bejelölünk, majd a cementpéppel szintig töltjük és lezárjuk. A feladott folyadék mennyiségét 24 és 48 óra múlva pipettával leszívjuk a felületről és megmérjük a tömegét. A kivérzés mértéke nem haladhatja meg az 1 V/V\%ot.

A zsugorodást egyszerüen, manuális Vicat-készülékkel megmérhetjük úgy, hogy összehasonlítjuk a cementkő szintjét a bejelölt kezdeti szinttel. A kivérzés mértékének szabványos meghatározására az MSZ EN 480-4 szabvány adhat támpontot. Ez a szabvány a betonhoz szükséges keverővíz relatív mennyiségének meghatározására szolgál.

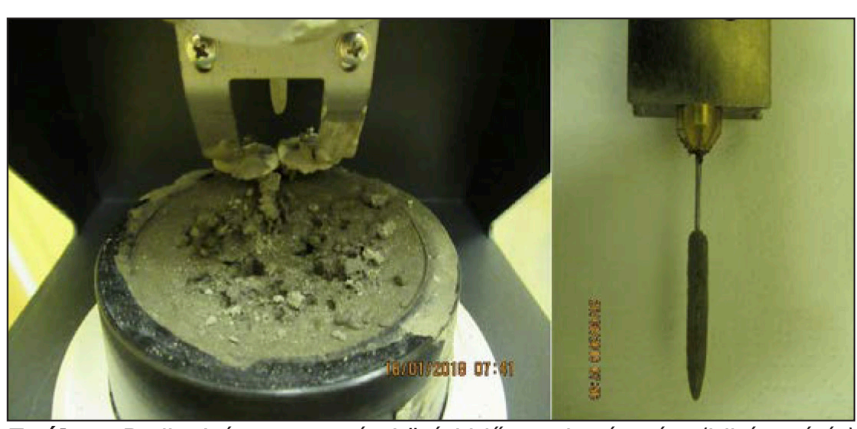

5. ábra: Radioaktív cementpép kötési idő meghatározása (hibás mérés)

A módszerhez egy levehető fedelü, $250 \pm 10 \mathrm{~mm}$ belső

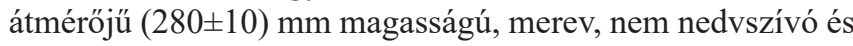
nem reakcióképes anyagból készült edényt kell használni. Ebbe kell betölteni három lépésben, tömörítés mellett a friss betont. A megtöltött edény felületét le kell simítani, és ki kell számolni a friss beton tömegét. Az elkészített mintát lefedve vízszintes, rázkódásmentes felületre kell helyezni, $20 \pm 2{ }^{\circ} \mathrm{C}$-on, min. $65 \%$ relatív páratartalom mellett. 10 percenként le kell szívni a beton felületéről a feladott folyadék mennyiséget pipettával, majd 40 perc elteltével 30 percenként a vérzés megszűnéséig.

Ahogy látható, a szabványhoz (mint a beton szabványokhoz általában) nagyobb mennyiségü mintára van szükség, amely esetünkben nagyobb sugárdózissal járna, ezen kívül a mintavétel a pép felületét károsíthatja, illetve felkavarhatja a friss betont. Ráadásul ekkora méretben a szabványban leírt páratartalom és hömérséklet követelményt nem tudjuk biztosítani.

A nemzetközi irodalomban (Gökçe et al., 2018) azonban találtunk egy olyan készüléket, amely alkalmas lehet a radioaktív cementpépek kivérzésének meghatározására. Gökçe és munkatársai szerint a beton vizsgálatát egy átalakított szabványos edényben mérték (6. ábra). A henger közepére az edény alján áthaladó $22 \mathrm{~mm}$ átmérőjü csövet tettek, úgy hogy a magassága az edény fala alatt legyen $6 \mathrm{~mm}$-el.

Az edényt a töltés idejére egy dugóval ellátott simítóeszközzel látták el, amely megakadályozta, hogy a beton a lefolyócsőbe kerüljön, illetve a töltés végén a felület könnyen lesimítható legyen. A feladott vizet a lefolyócső alján elhelyezett edényben gyüjtötték össze, ami már könnyen mérhetö.

A fenti eszköz analógiájára terveztünk egy egyszerübb, könnyebben kezelhető és sugárvédelmi szempontból is 


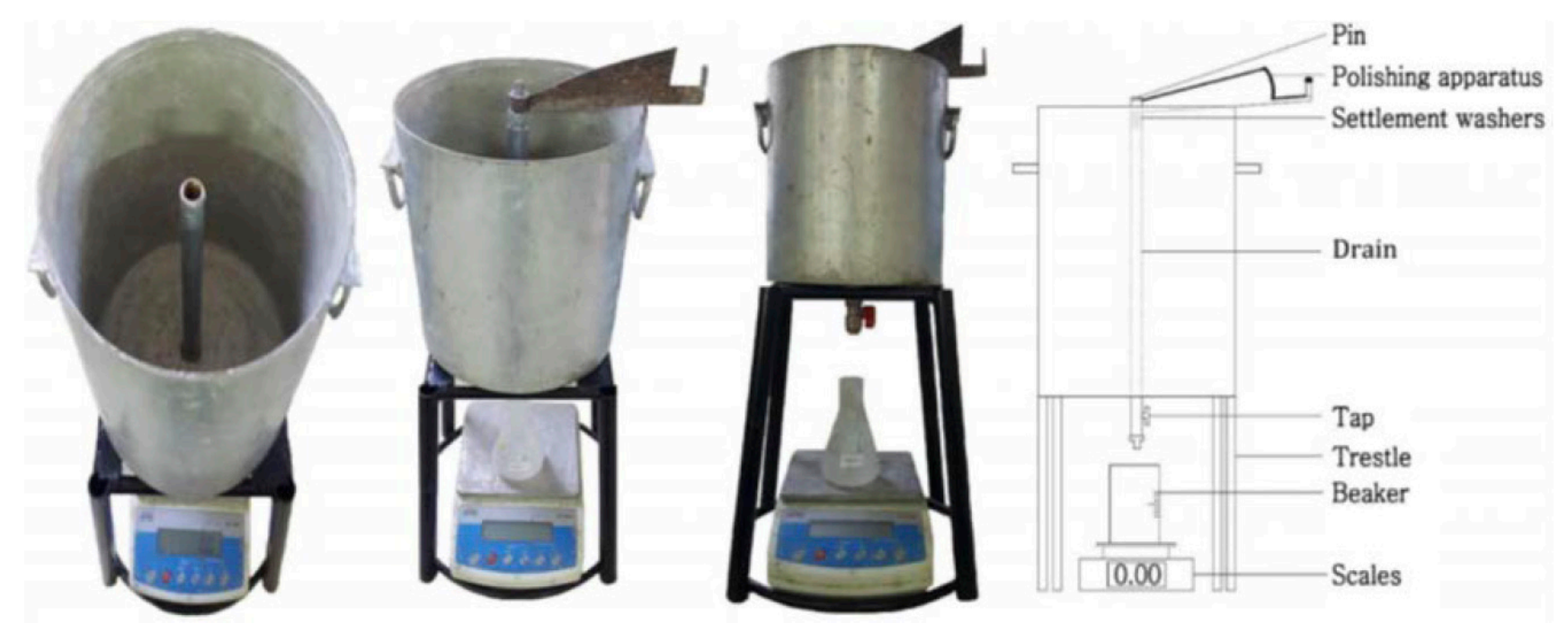

6. ábra: Módosított szabványos kivérzés mérőedény (Gökçe et al., 2018)

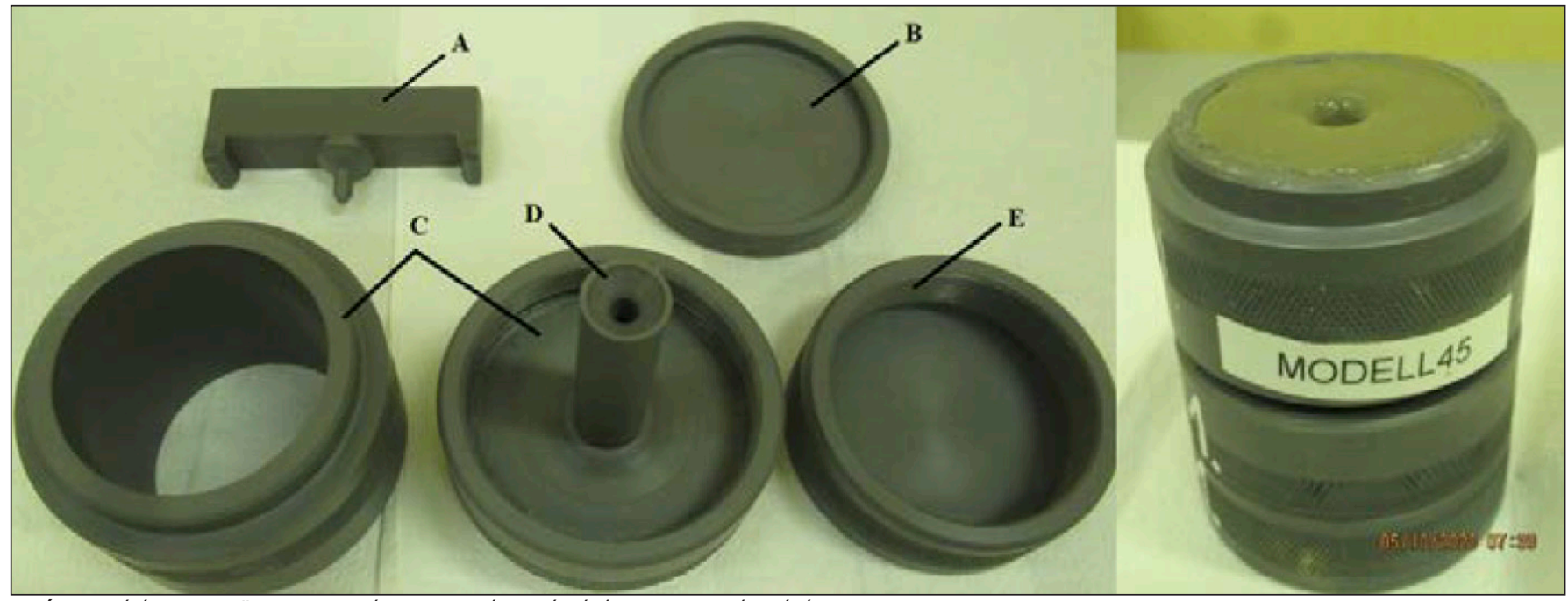

7. ábra: Kísérleti eszköz a radioaktív cementpép kivérzésének meghatározására

előnyösebb (kisebb) kivérzésmérő eszközt (7. ábra). Az MSZ EN 480-4 szabványban megadott edény méreteit ötödére csökkentettük, így a henger belső átmérője $50 \mathrm{~mm}$, a magassága pedig $56 \mathrm{~mm}$ lett.

Az eszköz egy szétcsavarható, 15 mm átmérőjü vízelvezető csővel (D) ellátott edényből (C), egy menetes folyadékgyüjtő tálkából (E) és egy fedélből áll (B). A cementpép betöltésének idejére a kupakkal ellátott simítót (A) a vízelvezető csőbe kell helyezni, majd a müvelet végén körbe forgatva a felület lesimítható. A pép felületén összegyűlt folyadék a folyadékgyüjtő tálkába folyik.

Töltéskor ügyelni kell arra, hogy a kupakkal ellátott simítót csak akkor szabad eltávolítani, ha elérte a pép megfelelő konzisztenciáját, hogy ne kerüljön cementpép a lefolyócsőbe.

\subsection{Radioaktív cementkő vizsgála- tok}

\subsubsection{Kioldódásvizsgálat}

A radioaktív hulladékok végleges elhelyezési koncepciója az ún. többszörös gátrendszer (multi-barrier) megközelítésen alapul, mely a müszaki, ember alkotta gátak és a geológiai környezet kombinációja. A müszaki gátrendszerek célja, hogy a radioizotópoknak csak kismértékü kiszabadulását engedje meg hosszú időtartamon keresztül. Ez a cél kis kioldódású hulladékformával, a hulladék izolációját egy ideig biztosító csomagolással és a csomagolás körüli térkitöltéssel valósítható meg. A térkitöltés korlátozza a víz és az oldatok mozgását, kedvező kémiai feltételeket teremt, valamint bizonyos fokú adszorpciós tulajdonsággal bírhat a kioldódott izotópok megkötésére (Nős et al., 2010).

A kioldási vizsgálat alapját egy féldinamikus módszer képezi, melynek során egy hengeres próbatestet kioldó közegbe (ioncserélt víz) mártanak, majd azt meghatározott idöközönként kicserélik, és a csere után meghatározzák a próbatestből kioldódott, vizsgált elemek koncentrációját, illetve a kioldódott anyag mennyiségét. Ez a próbatestben eredetileg jelenlévő összmennyiséghez képest adja a differenciális kioldási százaléktörtet (IFL - Incremental Fraction Leached). A teszt időtartama alatt akkumulált résztörtekből kumulatív kioldási százaléktörtet (CFL - Cumulative Fraction Leached) kapunk. A teszt során, minél gyakrabban cseréljük a próbatest körül a kioldó közeget, annál inkább válik alkalmazhatóvá a folyamat leírására Fick I. törvénye, ellenben annál kisebb kioldott anyagmennyiséget tudunk mérni, ami növeli a mérési hibát, ezért a teszt során alkalmazott mérési periódusok igyekeznek megfelelni mindkét feltételnek.

A diffúziós együttható egy kémiai anyag jellemzője, amely kifejezi a koncentrációgradiensét egy adott közegben való stacionárius áramlása során (Fick I. törvénye): 
$j=-D \frac{d c}{d x}$

ahol $j$ a diffúziós áramsűrüség, $D$ diffúziós tényező, $c$ a koncentráció

Fick II. törvénye szerint a koncentráció időbeli változása egy adott helyen arányos a koncentrációgrádiens helyváltozásával az adott időpillanatban:

$$
\frac{\partial c}{\partial t}=D \frac{\partial^{2} c}{\partial x^{2}}
$$

A HÁK (Radioaktív Hulladékokat Kezelő Kft., 2018) elöírása szerint a folyékony radioaktív hulladék felhasználásával készült cementkő esetén az egyes izotópok effektív diffúziós állandója nem haladhatja meg a $10^{-7} \mathrm{~cm}^{2} / \mathrm{s}\left(10^{-11} \mathrm{~m}^{2} / \mathrm{s}\right)$ értéket, az ASTM C1308-08 szabványban szereplő vizsgálati módszerrel értékelve.

\subsubsection{Nyomószilárdság-mérés}

A folyékony radioaktív hulladék cementbe ágyazásának feladata, hogy a folyékony halmazállapotú oldatból olyan szilárd terméket állítson elö, amely megfelel az NRHT hulladékátvételi követelményeinek (HÁK). A cementező technológiával minél nagyobb mennyiségű folyékony hulladék feldolgozása a cél a legkisebb térfogatnövekedés mellett. Tehát a maximális v/c tényező alkalmazásával kell biztosítani a HÁK-ban meghatározott min. $10 \mathrm{MPa}$ nyomószilárdságot.

A cement kémiai vízigénye $23-28 \%$, de a bedolgozáshoz szükséges konzisztencia eléréséhez 0,3 - 0,4 v/c tényező szükséges. A kötés következtében a cementkő zsugorodni kezd (korai, vagy plasztikus zsugorodás) és kialakulnak a felületére is kivezető kapilláris pórusok (Kausay, 2002, Nehme, 2004). A cementkő a fentieken kívül tartalmaz a keverésből és a bedolgozásból származó légzárványokat is.

A cementkő szilárdsága a pórusmentesnek feltételezett cementkő szilárdságától és a cementkő porozitásától függ.

A szilárdság függvény Powers szerint:

$\mathrm{R}_{c, \square}=R_{c, \max }\left(1-\frac{p}{100}\right)^{n}$

ahol $R_{c, \max }$ a pórusmentesnek feltételezett cementkő kockaszilárdsága (kb. $200 \mathrm{MPa}), p$ a porozitás, $n$ hatványkitevő (kb. 4,7) (Balázs, 1994).

A nyomószilárdság mérésével a porozitáson keresztül a cementkő kioldódási tulajdonságaira is következtethetünk. A nagyobb porozitás több kapillárissal, így nagyobb felülettel jár együtt, a lazább szerkezetü pórusokba könnyebben behatol a víz, és könnyebben kioldódhatnak a radioaktív izotópok.

\subsubsection{A sablonok tesztelése}

A nyomószilárdság-mérést a kísérletek kezdetén az MSZ EN 196 szabványnak megfelelö törőgéppel és öntőformákkal végeztük a könnyebb kezelhetőség, és a kisebb mennyiségü radioaktív törmelék keletkezése miatt. Már ekkor is tapasztaltuk, hogy a cementpép kis mértékben kifolyik a formákból, illetve a cementpép erőteljesen korrozív tulajdonságú.

A végleges receptúra kialakítása után, a félüzemi próbák során már az MSZ EN 12390-1 szabványnak megfelelő 150 mm élhosszúságú acél öntőformát is használtunk. A tapasztalatok azonban azt mutatták, hogy a cementpép kifolyik (kvázi szürődik) a forma illesztéseinél. A szivárgás megakadályozására szilikonos és teflonos tömítéseket alkalmaztunk, amely sok esetben bevált, viszont nagyon hosszadalmassá tette a mintelökészítést, és sok másodlagos hulladékkal járt a próbatest kizsaluzása. Ezeknél az öntőformáknál a cementpép agresszív korróziós viselkedése is problémát jelentett, mindössze egy használat után a pép lemarta a sablon festésének jelentős részét, ill. károsította a forma belső felületét, ezáltal a próbatestek felülete is egyenetlen lett.

A szétnyitható sablonok helyett végül az egyszerü, sürített levegővel kizsaluzható sablonokat alkalmaztuk. Ezek előnye, hogy nem korrodálódnak, nincs szükség szigetelésre és könnyüek (kb. $1 \mathrm{~kg})$. A hátrányuk viszont, hogy a kizsaluzásukhoz sürített levegőre van szükség, amelynek eredménye elég bizonytalan: a próbatest megakadhat, és sérülhet.

\subsubsection{A próbatest kizsaluzása és tárolása}

A próbatesteket a lefedett öntőformában elöször egy klimatizált $\left(20 \pm 5^{\circ} \mathrm{C}\right)$ átmeneti tárolószekrénybe fogjuk helyezni. Minden sablon alá kármentő tálca kerül az esetleges szivárgás felfogására. A radioaktív bepárlási maradékok felhasználásával készült próbatestek kizsaluzása csak 7 - 10 napos korban lehetséges - az MSZ EN 12390-2 szabványban leírt 3 nap helyett - az oldat nagy $\left(\mathrm{kb} .180 \mathrm{~g} / \mathrm{dm}^{3}\right)$ bórsav és szerves anyag tartalmának kötés késleltető hatása miatt.

A kizsaluzást követően a 7 - 10 napos próbatesteket megtisztítjuk, feliratozzuk, kalibrált tolómérővel lemérjük a méreteit, és ellenőrizzük az oldalak párhuzamosságát. Megmérjük a próbatestek tömegét is, és az adatokból kiszámítjuk a cementkő testsűrüségét (MSZ EN 12390-7). A későbbiekben törésre kerülő (28 napos, esetleg 14 napos) próbatestek feliratozva klímakamrába kerülnek $20 \pm 1{ }^{\circ} \mathrm{C}$-on és $90 \%$ relatív páratartalom mellett. A tárolási körülményeket folyamatosan regisztrálni fogjuk. A szabvány szerinti vízalatti tárolást azért kerüljük, mert a próbatestekből izotópok oldódnának a vízbe.

A 28 napos, bepárlási maradék felhasználásával készült cementkövek nyomószilárdsága átlagosan $35 \mathrm{~N} / \mathrm{mm}^{2}$, amely jelentősen meghaladja a HÁK-ban (Radioaktív Hulladékokat Kezelö Kft., 2018) leírt min. 10 N/mm² értéket.

\subsubsection{A mérés kivitelezése}

A nyomószilárdság-mérésnél az egyik legfontosabb szempont a sugárvédelmi szabályok betartása, és a belső sugárterhelés (inkorporáció) elkerülése. A vizsgálatot nagyon körültekintően kell végezni, mivel a próbatesttel végzett mủveletek során nyílt radioaktív forrással kerülünk közvetlen kapcsolatba. A müvelet során a szokásos egyéni védőfelszerelésen kívül gumikesztyü, légzésvédő és cipővédő lábzsák használata is kötelező. Ezen kívül gondoskodni kell a nyomószilárdságmérő készülék törőkereteinek elszívásáról, és a mérés során keletkező kiporzás csökkentéséről. Ebből a célból a próbatestek nyomófelületre merőleges oldalait elasztikus fóliával (Parafilm) fogjuk betekerni, amely nem akadályozza a minta keresztirányú tágulását. A próbatest teljes egészét nem boríthatjuk be ezzel az anyaggal, mert biztosítani kell a nyomólapok és a minta felületén fellépő súrlódást. A fóliabevonattal csökkentenénk a tapadást, amely gyengítené a keresztirányú nyúlást gátló hatást, így meghamisítaná a mérési eredményeket (Balázs, 1994).

A nyomószilárdság-mérö készülékeket, így a törökereteket is természetesen építőipari termékek vizsgálatára tervezték, amelyek esetén nem okoz gondot a mérés során keletkező kiporzás és törmelék szétszóródása. A radioaktív cementkő 


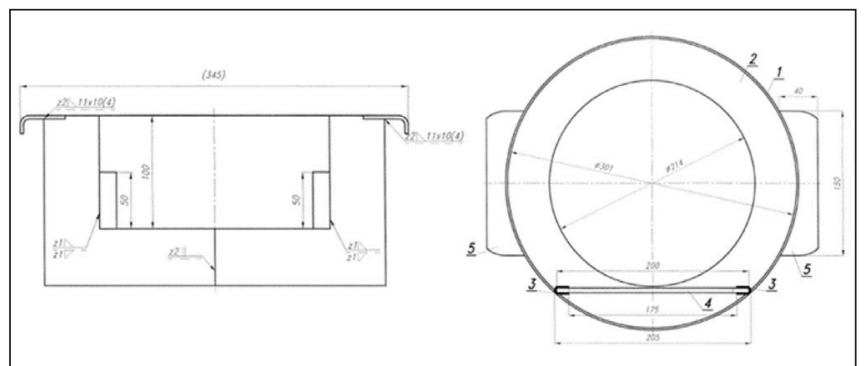

8. ábra: Törmelékgyűjtő tálca: 1 oldallemez, 2 pozícionáló tárcsa, 3 vezetősín, 4 kémlelő ablak, 5 emelőfül

vizsgálatoknál azonban az elsődleges a kontamináció, és az inkorporáció megelőzése, ill. az ALARA elv betartása. A mérés során keletkező törmelék összegyüjtésére terveztünk egy tálcát, amely csökkenti a készülék és a laboratórium kontaminációját (8. ábra).

A tálca vastagsága kevesebb, mint az MSZ EN 12390-3 szabványban megadott min. $23 \mathrm{~mm}$, a könnyebb kezelhetőség céljából.

A méréseket kezdetben 7, 14 és 28 napos korban tervezzük elvégezni, de az oldatban lévő borát és szerves anyag tartalom miatt a próbatest kizsaluzhatóságának időpontja bizonytalan. Az öntőformák tesztelése során sok esetben csak 10 napos korban lehetett eltávolítani a sablont, ezekben az esetekben eltekintünk a 14 napos vizsgálattól.

\section{KÖVETKEZTETÉSEK}

A laboratóriumi vizsgálatok során a radioaktív cementpépet és a kötés után kialakuló cementkövet a betonvizsgálati szabványok alapján vizsgáltuk, amennyiben ez lehetséges volt. Figyelembe kellett vennünk azonban az ALARA elvet, így a betonvizsgálatoknál használt minták mennyiségét ésszerü mértékben csökkentettük. Ezt a döntést azért is hozhattuk meg, mert a betonnal ellentétben a radioaktív cementpép nem tartalmaz adalékanyagokat, ezért kis mennyiségben is homogénnek tekinthetö.

A kísérletek alapján a cementpép testsürüségét az MSZ EN 12350-6 szabvány alapján fogjuk végezni azzal az eltéréssel, hogy a méréshez 11 cementpépet fogunk használni.

A konzisztencia méréshez azonban nem alkalmazható az MSZ EN 12350-5 szabvány a cementpép kis viszkozitása, ezáltal várhatóan nagy terülése miatt. Ez a vizsgálat ésszerütlenül nagy kontaminációt okozna, és felesleges sugárterheléssel járna, ezért megtartottuk a kezdeti kísérletek alatt alkalmazott Suttard-féle terülés mérést.

Mivel a beton kötési idejének mérésére nincs szabvány, ezért erre a vizsgálatra az MSZ EN 196-3 cementvizsgálati szabványban előírt Vicat-módszert alkalmaztuk. A vizsgálatra automata Vicat-készüléket fogunk használni, mert a cementpép boráttartalma késlelteti a cement kötését. A szabványos Vicat-gyürüt módosítanunk kellett, ezért terveztünk egy menetes, zárható, de a szabványban írtaknak megfelelő Vicatöntőformát.

A kivérzés mértékének méréséhez az MSZ EN 480-4 szabvány által elöírt módosított mérőeszközt kívánjuk használni, amely a kezdeti kísérletek során megfelelönek látszik. Ebben az esetben is a sugárdózis csökkentésének érdekében a vizsgálandó minta számának csökkentésére volt szükség, ami a cementpép homogenitása miatt szintén kivitelezhető. Az eszköz tervezésének alapját Gökçe és munkatársai által készített módosított öntőforma adta, amelynek méretét ötödére csökkentettük, és leegyszerüsítettük.
A zsugorodás mérést a kiindulási kísérletek során alkalmazott, $40 \mathrm{~mm}$ magasan bejelölt fedővel ellátott müanyag pohárban fogjuk elvégezni. A mérés során manuális Vicat-készülék segítségével határozzuk meg a kötés során bekövetkező szintkülönbséget.

A nyomószilárdság vizsgálatára az MSZ EN 12390-1 szabványban előírt próbatestek öntőformáinak tesztelése azt az eredményt hozta, hogy erre a célra a legalkalmasabbak a sürített levegővel kizsaluzható műanyag öntőformák. A radioaktív cementpép ugyanis korrozív hatása miatt korrodálja az acél öntőformákat, kis viszkozitása és adalékanyag hiánya miatt pedig kifolyik a sablonból. Az öntőforma zárócsavarját még ebben az esetben is tömíteni kell. A próbatestek tárolása (érlelése) $20 \pm 1{ }^{\circ} \mathrm{C}$ on, $90 \%$ relatív páratartalmú klímakamrában lehetséges, mivel a vízalatti tárolás további problémát okozna a víz radioaktív kontaminációja folytán.

A nyomószilárdság-mérést az MSZ EN 12390-3 szabvány alapján kívánjuk elvégezni, de az elsődleges célunk a pontos mérésen kívül a radioaktív kontamináció elkerülése. Ennek érdekében a próbatest terhelésre merőleges oldalát elasztikus fóliával (Parafilm) kell bevonni a kiporzás megakadályozására, valamint törmelékgyüjtő tálcát kell használni a radioaktív törmelék felfogására.

A kioldódás vizsgálatot, azaz a diffúziós együttható meghatározását az ASTM C1308 szabvány szerint fogjuk végezni, és attól semmilyen formában nem térünk el. A vizsgálatot minden szóba jöhető izotópra elvégezzük, amelyek közül a legfontosabbak a ${ }^{60} \mathrm{Co},{ }^{137} \mathrm{Cs}$ és a ${ }^{3} \mathrm{H}$. A kioldó oldatokat $\gamma$ és $\beta$, esetleg $\alpha$ spektrometriásan analizáljuk, majd a szabványban szereplő vizsgálati módszerrel kiértékeljük.

A cementezett radioaktív hulladékvizsgáló laboratórium a tanulmányban taglalt vizsgálatok és eszközfejlesztések következtében kellő mértékben felkészült a cementező technológiából származó radioaktív cementpép ellenőrzésére. A müködése során biztosítani fogja a Paksi Atomerőmüből kikerülő, és végleges tárolásra kerülő hulladékcsomagok szigorú minőségellenőrzését, amellyel garantálja az NRHT által elöírt hulladék átvételi követelmények maradéktalan betartását.

\section{HIVATKOZÁSOK}

155/2014. (VI. 30.) Korm. rendelet a radioaktív hulladékok átmeneti tárolását vagy végleges elhelyezését biztosító tároló létesítmények biztonsági követelményeiről és az ezzel összefüggő hatósági tevékenységről

487/2015. (XII. 30.) Korm. rendelet az ionizáló sugárzás elleni védelemről és a kapcsolódó engedélyezési, jelentési és ellenőrzési rendszerről

2015. évi CLXXXV. törvény a hulladékról szóló 2012. évi CLXXXV. törvény, valamint az egyes közszolgáltatások ellátásáról és az ezzel összefüggő törvénymódosításokról szóló 2013. évi CXXXIV. törvény módosításáról

Balázs Gy. (1994), „Építőanyagok és kémia”, Müegyetemi Kiadó, Budapest

Blasdalae, W. C.; Slansky, C. M. (1939), „The Solubility Curves of Boric Acid and the Borates of Sodium", Journal of the American Chemical Society, April, https://doi.org/10.1021/ja01873a043

Csetényi, L. J.; Glasser, F.P. (1995), „Borate retardation of cement set and phase relations in the system $\mathrm{Na}_{2} \mathrm{O}-\mathrm{CaO}-\mathrm{B}_{2} \mathrm{O}_{3}-\mathrm{H}_{2} \mathrm{O}$, Advances in Cement Research Vol. 7 (25) Jan., 13-19, https://doi. org/10.1680/adcr.1995.7.25.13

Coumes, C. C. D. (2003), „Cementation of a low-level radioactive waste of complex chemistry Investigation of the combined action of borate, chloride, sulfate and phosphate on cement hydration using response surface methodology", Cement and Concrete Research Vol. 33 305-316, https://doi.org/10.1016/S0008$\underline{8846(02) 00943-2}$ 
Davraz, M. (2010), „The Effects of Boron Compounds on the Properties of Cementitious Composites", Science and Engineering of Composite Materials, Vol. 17, Jan., 1-18, https://doi.org/10.1515/ SECM.2010.17.1.1

Gökçe, H. S.; Andiç-Çakir, Ö. (2018), „Development of a Functional Bleeding Test Apparatus for Fresh Concrete", Journal of Testing and Evaluation, Vol. 47, https://doi.org/10.1520/JTE20170396

IAEA (1996), Processing of Nuclear Power Plant Waste Streams Containing Boric Acid. TRS No. 911

Kausay T. (2002), „Pórusszerkezet”, Beton szakmai havilap, 04/2002 14

Kappel V. (2021), A cementező technológia bemutatása, Személyes közlés, 2021

Kratochvíl, J.; Opravil, T; Pavel, D. (2014), „The effect of boron and its compounds on setting of portland cement", Advanced Materials Research Vol. 1000 16-19, https://doi.org/10.4028/www.scientific. net/AMR.1000.16

MVM Paksi Atomerömü Zrt. (2019), ,Az MVM Paksi Atomerőmü Zrt. Radioaktív hulladékainak kezelése, tárolása és elhelyezése", Éves jelentés 2019

Nehme, S. G. (2004), „A beton porozitása”, PhD értekezés

Nős B.; Ormai P.; Fritz A.; Bérci K.; Feil F. (2010), „A Bátaapáti NRHT hulladék átvételi rendszere, és ennek alkalmazása egy jellemző hulladéktípusra", Nukleon 03/2010, ISSN: 1789-9613

Pungor E. (1987), „Analitikusok kézikönyve”, Müszaki Könyvkiadó, Budapest, 1987

Radioaktív Hulladékokat Kezelő Kft. (2018), „Hulladék átvételi követelmények”, NRHT üzemeltetést megalapozó biztonsági jelentés (RHK-K-076B/16), 11. fejezet: Üzemeltetési feltételek és korlátok

Sedaghat, A.; Zayed, A.; Sandberg, P. (2013), „Measurement and Prediction of Heat of Hydration of Portland Cement Using Isothermal Conduction Calorimetry", Journal of Testing and Evaluation, Vol. 41, https://doi.org/10.1520/JTE20120272.

Spence, R. D.; Shi, C., (2005), „Stabilization and Solidification of Hazardous, Radioactive, and Mixed Wastes", CRC Press, New York, NY, USA, 2005

Rolo, L. (2013), „Monitoring of the Cement Hydration Behavior and Determination of Non-Standard Laboratory Indicators of Setting Time", Thesis for: MEng in Cilvil Engineering, https:// doi.org/10.13140/2.1.1963.6480

Wang, K.; Ge, Z.; Grove, J.; Ruiz, J. M.; Rasmussen, R.; Ferragut, T. (2007), ,Developing a Simple and Rapid Test for Monitoring the Heat Evolution of Concrete Mixtures for Both Laboratory and Field Applications", InTrans Project Reports, Vol. 153., http://lib. dr.iastate.edu/intrans_reports/153

Hivatkozott szabványok listája

MSZ EN 196-1: 2016 Cementvizsgálati módszerek. 1. rész: A szilárdság meghatározása

MSZ EN 196-3: 2017 Cementvizsgálati módszerek. 3. rész: A kötési idő és a térfogat-állandóság meghatározása

MSZ 4798: 2016 Beton. Müszaki követelmények, tulajdonságok, készítés és megfelelőség, valamint az EN 206 alkalmazási feltételei Magyarországon

MSZ EN 1015-3:2000 Falszerkezetei Habarcsok vizsgálati módszerei. 3. rész A friss habarcs konzisztenciájának meghatározása (ejtőasztallal)

MSZ EN 12350-5: 2019A friss beton vizsgálata. 5. rész: Terülésmérés MSZ EN 12350-6: 2019 A friss beton vizsgálata. 6. rész: Testsürüség MSZ EN 12390-1: 2013 A megszilárdult beton vizsgálata. 1. rész: A próbatestek és sablonok alak-, méret- és egyéb követelményei

MSZ EN 12390-2: 2019 A megszilárdult beton vizsgálata. 2. rész: Szilárdságvizsgálati próbatestek készítése és tárolása

MSZ EN 12390-3: 2019 A megszilárdult beton vizsgálata. 3. rész: A próbatestek nyomószilárdsága
ASTM C1308-08(2017) Standard Test Method for Accelerated Leach Test for Diffusive Releases from Solidified Waste and a Computer Program to Model Diffusive, Fractional Leaching from Cylindrical Waste Forms, ASTM International, West Conshohocken, PA, 2017, www.astm.org, https://doi.org/10.1520/C1308-08R17

Baranyi Attila (1978) okl. vegyész, okl. kémia szakos tanár, betontechnológus szakmérnök. Korábban radioanalitikával (radioaktív gyógyszerek minőségellenőrzése), majd folyékony radioaktív hulladékok kezelési technológiájának fejlesztésével foglalkozott: ultraszürö-membránok, szorbensek tesztelése, nedves oxidációs eljárások kidolgozása. Jelenleg a Paksi Atomerőmüben létesítés alatt álló radioaktív hulladékcementező technológiához kapcsolódó laboratórium kialakításával, az alkalmazott eszközök fejlesztésével, tesztelésével és a vizsgálati módszerek kidolgozásával foglalkozik.

Dr. Kopecskó Katalin (1961) okl. vegyészmérnök (BME, Vegyészmérnöki Kar, 1990), okl. betontechnológus szakmérnök (2004), $\mathrm{PhD}$ (2006), egyetemi docens a BME Geotechnika és Mérnökgeológia Tanszékén. Fő érdeklődési területei: építőanyagok tartóssága, anyagvizsgálat és fázisátalakulások elemzése röntgendiffrakcióval és termoanalitikával. A $\boldsymbol{f} \boldsymbol{b}$ Nemzetközi Betonszövetség és a fib Magyar Tagozatának, valamint az MSZT/MB 102 „Cement és mész” Nemzeti szabványosító müszaki bizottság tagja.

Feil Ferenc (1970) okl. vegyészmérnök (BME, Vegyészmérnöki Kar, 1995) Munkahelyei: Atomix Kft., MVM Paksi Atomerőmü Zrt. Szakterülete a szilárd és folyékony radioaktív hulladékok kezelése, kondicionálása, amely területen technológus mérnökként kezdett, jelenleg osztályvezetőként irányítja a szakterület tevékenységeit az atomeröműben. Érdeklődési területei: membrántechnológiák, cézium szelektív szorbensek, folyékony radioaktív hulladékok szilárdítása cementezéssel.

Lukáš Grič (1977) vegyészmérnök, kísérleti szakember. A Chemcomex, a.s. fejlesztési osztályán dolgozik 18 éve. Érdeklődési területei a radioaktív hulladékfeldolgozás, és a veszélyes hulladékégetőkből származó pernye kezelése.

\section{RADIOACTIVE WASTE EMBEDDING IN CEMENT MATRIX AND THE ESTABLISHMENT OF CEMENTED WASTE TESTING LABORATORY AT PAKS NUCLEAR POWER} PLANT

Attila Baranyi - Katalin Kopecskó - Ferenc Feil - Lukáš Grič

For the treatment of low and intermediate level radioactive waste generated at the Nuclear Power Plant of Paks, a new compact waste package will be created with a new cementing technology currently under construction. During the operation the solid waste will be placed in steel drums than these drums will be placed into a thin-walled steel container. The cavity volume in solid waste is filled with cemented slurry made using liquid radioactive waste. Compact waste packages must comply with the waste acceptance criteria described in the National Radioactive Waste Repository Safety Report.

The task of the cemented waste testing laboratory, which is under construction is the in-service inspection of the properties of the finished cemented material, furthermore to determine the compressive strength and leachability (diffusion coefficient) of the specimens made thereof. During the installation of the laboratory and testing of the devices used in the cement/concrete industry, it turned out that in many cases special moulds are required due to the low viscosity and corrosive properties of the radioactive paste. In addition, the collection of debris generated during the measurement of the compressive strength of radioactive cement stone and the minimization of dusting are important requirements. 